\title{
Pulmonary function test in Tropical Pulmonary Eosinophilia
}

\author{
Kumar $\mathbf{R}^{1}$, Mourya $\mathbf{S}^{2}$ \\ ${ }^{1}$ Dr Ratan Kumar, Assistant Professor of Pulmonary Medicine, L N Medical College, Bhopal, MP, ${ }^{2}$ Dr Sudhir Mourya, \\ Associate Professor of Medicine, Index Medical College, Indore, MP, India,
}

Address for correspondence: Dr Ratan Kumar, Email: ratan_vaish@yahoo.co.in

\begin{abstract}
Introduction: Tropical pulmonary eosinophilia (TPE) is a syndrome of wheezing, fever and eosiniphilia seen predominantly in the Indian subcontinent and other tropical areas. The syndrome results from immunologic hyperresponsiveness to human filarial parasites, Wuchereria bancrofti and Brugia malayi. Absolute eosinophilia counts are usually more than 3,000 cells $/ \mathrm{mm} 3$. Lung functions are severely compromised. Pulmonary function tests may show a mixed restrictive and obstructive abnormality with a reduction in diffusion capacity. The mean values of expiratory flow rates were significantly decreased. Oral DEC (6 mg/kg per day) for 3 weeks is treatment of choice. Methods: A total of 61 , clinic-radiologically and haematologically suspected cases of tropical pulmonary eosinophilia were included in study along with 39 healthy controls. Pulmonary functions, which included forced vital capacity (FVC), forced expiratory volume in one second $\left(\mathrm{FEV}_{1}\right), \mathrm{FEV}_{1} / \mathrm{FVC}$ Ratio, maximum mid expiratory flow rate (MMEFR) and peak expiratory flow rate (PEFR) were observed in study cases and control. Results: The mean values \pm S.D. of all spirometric parameters showed low value in cases in comparison to control. Statistically all parameters showed highly significant difference (' $p$ ' value were $<0.001$ ) except in FEV1/FVC ratio ( $p$ value was $>0.05$ ). After the treatment with DEC the mean values \pm S.D. of all parameters in cases showed improvement but the values were remained still below the control value. Conclusion: This disease, if left untreated or treated late, may lead to long-term sequelae of pulmonary fibrosis or chronic bronchitis with chronic respiratory failure.
\end{abstract}

Key words: Tropical Pumlonary eosinophilia, Eosinophilia, Pulmonary function test, Diethylcarbamazepine.

\section{Introduction}

Tropical pulmonary Eosinophilia is an occult form of filariasis and is characterised by paroxysmal cough, breathlessness, nocturnal wheezing, diffuse reticulonodular infiltrates in chest X-rays and marked peripheral blood eosinophilia [1-4]. The syndrome results from immunologic hyper-responsiveness to human filarial parasites, Wuchereria bancrofty and Brugia malayi [4]. The term tropical pulmonary eosinophilia (TPE) was first coined by Weingarten in 1943. He described 81 patients with a syndrome of wheezing, fever, eosinophilia and bilateral mottling of the lungs [5].

Tropical Pulmonary Eosinophilia is commonly seen in areas endemic for filariasis i.e. in the Indian subcontinent, South East Asia, South America and Africa [2, 6,7]. In India, it is mostly found around the

Manuscript received: $22^{\text {nd }}$ Mar 2014

Reviewed: $25^{\text {th }}$ Mar 2014

Author Corrected: $3^{\text {rd }}$ April 2014

Accepted for Publication: $7^{\text {th }}$ May 2014 coastal regions from Maharashtra to Kerala and West Bengal to Tamil Nadu [2]. The prevalence of TPE in various settings in India has varied from 0.5 per cent among children in TamilNadu 10 to 9.9 per cent among jail inmates in Patna [8]. Some cases are also reported in non endemic countries because of travel to or immigration from endemic areas. In fact, persons travelling to endemic areas may be more prone as they lack natural immunity to filarial antigens [9]. It has been estimated that at least 120 million persons are infected with mosquito-borne lymphatic filariasis worldwide [10]. It is seen in less than $1 \%$ of filarial infection [11]. The disease occurs predominantly in males, with male to female ratio of $4: 1$ and is mainly seen in children and young adults between the age 15 years and 40 years [24].

Sputum is usually scanty, viscous and mucoid. Sputum often shows clumps of eosinophils. Bilateral scattered rhonchi and rales may be heard on auscultation. 
Leukocytosis with an absolute increase in eosinophils in the peripheral blood is the hallmark of TPE. Spontaneous fluctuations in the eosinophilia count can occur. Absolute eosinophilia counts are usually more than 3 , cells 000 $/ \mathrm{mm} 3$ and may range from 5,000 to 80,000 . Erythrocyte sedimentation rate is elevated in $90 \%$ of cases and returns to normal following specific treatment [4]. Microfilariae are rarely seen in the peripheral blood. The chest radiological features of TPE include reticulonodular shadows predominantly seen in mid and lower zones and military mottling of $1-3 \mathrm{~mm}$ in diameter often indistinguishable from miliary tuberculosis [2]. Radiologic findings very often regress on treatment with DEC but many patients may show residual changes [12].

\section{Lung function changes}

Spirometry is usually mixed restrictive and obstruction which may be mild to moderate in degree $[2,13]$. In a study by Kuppurao et al the mean values of expiratory flow rates were significantly decreased in untreated TPE and while there was improvement with treatment, it was still below normal at one month [14]. Udwadia had reported a pure restrictive pattern on spirometry in 70 per cent patients and mixed disorder in 30 percent [2]. Vijayan et al also reported a low transfer factor for carbon monoxide (TLCO) as measured by the single breath method [15].

The standard treatment recommended by the World Health Organization for treatment of TPE is oral DEC (6 $\mathrm{mg} / \mathrm{kg}$ per day) for 3 weeks [16]. One month after the start of the treatment most patient show marked symptomatic and radiographic improvement and significant improvement in almost all aspects of lung functions including $\mathrm{FEV}_{1}, \mathrm{FVC}$, TLCO, expiratory flow rates [12, 17-19].

\section{Material \& Methods}

Present study was carried out in patients attending the Out Patients Department (O.P.D) and admitted in T.B. and chest ward of S.R.N. Hospital, Allahabad. The criteria for the selection of patients for inclusion in the present study were followed as described by Donohugh (1963).

\section{Major criteria (Donohugh, 1963)}

A. Pulmonary symptoms: an insidious dry, paroxysmal cough, especially nocturnal with breathlessness and wheezing.
B. Peripheral blood eosinophilia count greater then $2000 / \mathrm{mm}^{3}$.

C. Positive filarial complement fixing antibody.

D. Response to specific therapy with diethyl carbamazine, $6 \mathrm{mg} / \mathrm{kg}$ body weight (three times a day ) for six days.

\section{Minor criteria (Donohugh, 1963)}

A. Recent stay in an endemic area.

B. Age and sex affected (male in second and third decade).

C. Sibilant or sonorous rhonchi on basis.

D. Raised erythrocyte sedimentation rate (ESR)

D. Accompanying non specific symptoms of malaise, fatigue, anorexia, weight loss.

\section{Selection of the cases}

1. Age above 10 years

\section{Patients of both sexes}

3.Clinico-radiologically and haematologically suspected cases of tropical pulmonary eosinophillia.

The diagnosis of TPE is considered to be positive if all the four major criteria or three major and at least three minor criteria are fulfilled.

In our study facility of filarial complement fixing antibody test, was not available, so those patient who fulfilled at least three major and three or more minor criteria, were consider as a case of Tropical Pulmonary Eosinophilia.

Patients with a past history of chronic bronchitis, bronchial asthma, pneumonia, pleurisy, pulmonary tuberculosis, worm infestation, allergic reaction to drugs and history of having received DEC during the past six months were excluded from the study.

Detailed clinical history of every patient was taken and thorough physical examination with special emphasis on respiratory system was done. Routine investigation like $\mathrm{Hb}$, Stool, Urine, and Sputum for acid fast bacilli, X-ray chest, pulmonary function test was done.

Because no comparative study is found to be conducted in past few years, this study is planned with aim to 
evaluate the disease pattern and response with standard drug in recent years.

\section{Observation \& Results}

The present study was carried out in S.R.N. Hospital, Allahabad. A total of 61, clinic-radiologically and haematologically suspected cases of tropical pulmonary eosinophilia were included in the study. A total of 39 healthy controls were included in the study. Pulmonary functions, which included forced vital capacity (FVC), forced expiratory volume in one second ( $\left.\mathrm{FEV}_{1}\right)$, $\mathrm{FEV}_{1} / \mathrm{FVC}$ Ratio, maximum mid expiratory flow rate (MMEFR) and peak expiratory flow rate (PEFR) were observed in study cases and control.

All 61 cases were treated with standard dose of diethylcarbamazine citrate $(6 \mathrm{mg} / \mathrm{kg} /$ day $)$ in three divided doses for 21 days. Follow up pulmonary function test and haematological test could be possible only in 13 cases out of 61 , after treatment with diethylcarbamazine.

Table No.1 (A): Age and Sex wise distribution of cases

\begin{tabular}{|l|l|l|l|l|l|l|}
\hline \multirow{2}{*}{$\begin{array}{l}\text { Age group } \\
\text { (years) }\end{array}$} & \multicolumn{2}{|l|}{ Male $(\mathbf{n}=\mathbf{4 9})$} & Female (n= 12) & \multicolumn{2}{l|}{ Total $(\mathbf{n}=\mathbf{6 1})$} \\
\cline { 2 - 7 } & No & \% & No & \% & No & \% \\
\hline $10-20$ & 17 & 34.7 & 4 & 33.3 & 21 & 34.4 \\
\hline $21-30$ & 21 & 42.9 & 3 & 25.0 & 24 & 39.3 \\
\hline $31-40$ & 8 & 16.4 & 1 & 8.3 & 9 & 14.8 \\
\hline $41-50$ & 1 & 2.0 & 2 & 16.7 & 3 & 4.9 \\
\hline$>50$ & 2 & 4.0 & 2 & 16.7 & 4 & 6.6 \\
\hline Mean \pm S.D. & $25.92 \pm 9.96$ & $35.20 \pm 16.85$ & $27.44 \pm 11.72$ & \\
\hline
\end{tabular}

Out of 61 cases of TPE, there were 49 males (80.3\%) and 12 females (19.7\%), approximately in ratio of 4:1.

The maximum number of cases 24 (39.3\%) were seen in age group 21-30 years. The maximum number of male cases 21 (42.9\%) and female cases 4 (33.3\%) were seen in age groups of 21-30 and 10-20 years respectively.

Table No.1 (B): Age and Sex wise distribution of control

\begin{tabular}{|l|l|l|l|l|l|l|}
\hline \multirow{2}{*}{ Age group (years) } & \multicolumn{2}{|l|}{ Male (n= 30) } & \multicolumn{2}{l|}{ Female (n= 9) } & \multicolumn{2}{l|}{ Total (n= 39) } \\
\cline { 2 - 7 } & No & $\%$ & No & \% & No & $\%$ \\
\hline $10-20$ & 6 & 20.0 & 3 & 33.4 & 9 & 23.1 \\
\hline $21-30$ & 15 & 50.0 & 2 & 22.2 & 17 & 43.6 \\
\hline $31-40$ & 6 & 20.0 & 1 & 11.1 & 7 & 17.9 \\
\hline $41-50$ & 1 & 3.3 & 1 & 11.1 & 2 & 5.1 \\
\hline$>50$ & 2 & 6.7 & 2 & 22.2 & 4 & 10.3 \\
\hline Mean \pm S.D. & $25.92 \pm 9.96$ & & $35.20 \pm 16.85$ & & $27.44 \pm 11.72$ & \\
\hline
\end{tabular}

Out of 39 control, there were 30 males $(77.0 \%)$ and 9 females $(23.0 \%)$.

The maximum number of control was in age group 21-30 years matched with distribution of cases. The maximum number of male control was in same age group (also match with male cases age group) and the maximum number of female control was in age group 10-20 years(same as in female case). 
Table No 2: Symptoms of 61 cases

\begin{tabular}{|l|l|l|}
\hline Symptoms & No. of cases $(\mathbf{n}=\mathbf{6 1})$ & Frequency (\%) \\
\hline Cough & 61 & 100.0 \\
\hline Dry cough & 29 & 47.5 \\
\hline Productive cough & 32 & 52.5 \\
\hline Breathlessness & 57 & 93.4 \\
\hline Wheezing & 28 & 45.9 \\
\hline Chest pain & 31 & 50.8 \\
\hline Fever & 18 & 29.5 \\
\hline
\end{tabular}

Commonest symptom was cough found in all cases (100.0\%). Dry cough was found in 29(47.5) while productive cough was found in 32(52.5\%). This was followed by breathlessness 57(93.4\%), chest pain 31 (50.8\%) \& wheezing 28(45.9\%).

Table No 3: Distribution of cases according to Absolute Eosinophil count level (AEC)

\begin{tabular}{|l|l|l|l|l|l|l|}
\hline \multirow{2}{*}{$\begin{array}{c}\text { ACE level } \\
\left(/ \mathbf{m m}^{\mathbf{3}}\right)\end{array}$} & \multicolumn{2}{|l|}{ Male $(\mathbf{n}=\mathbf{4 9})$} & \multicolumn{2}{l|}{ Female $(\mathbf{n}=\mathbf{1 2})$} & \multicolumn{2}{l|}{ Total $(\mathbf{n}=\mathbf{6 1})$} \\
\cline { 2 - 7 } & No & $\mathbf{\%}$ & No & $\mathbf{\%}$ & No & \% \\
\hline $2000-5000$ & 14 & 28.6 & 7 & 58.3 & 21 & 34.4 \\
\hline $5000-10,000$ & 14 & 28.6 & 4 & 33.4 & 18 & 29.5 \\
\hline$>10,000$ & 21 & 42.8 & 1 & 8.3 & 22 & 36.1 \\
\hline Total & $10,874.82 \pm 13,908.41$ & $5,561.83 \pm 3,098.28$ & $9,829.64 \pm 12,690.18$ \\
\hline
\end{tabular}

Maximum number of cases 22 (36.1) had absolute eosinophil count level more then $10,000 / \mathrm{mm}^{3}$. The maximum number of male cases $21(42.8 \%)$ had A.E.C. level more then $10,000 / \mathrm{mm}^{3}$ while the maximum number of female cases $7(58.3 \%)$

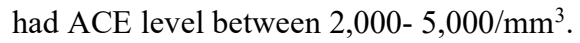

Table No 4(A): Distribution of mean values \pm S.D. of pulmonary functions in total cases according to different age groups

\begin{tabular}{|l|l|l|l|l|l|l|}
\hline $\begin{array}{l}\text { Age group } \\
\text { (years) }\end{array}$ & No. & FVC(lit) & FEV $\mathbf{l}(\mathbf{l i t})$ & $\begin{array}{l}\text { FEV } / \text { FVC } \\
(\mathbf{\%})\end{array}$ & $\begin{array}{l}\text { MMEFR } \\
\text { (lit/sec) }\end{array}$ & $\begin{array}{l}\text { PEFR } \\
\text { (lit/sec) }\end{array}$ \\
\hline $10-20$ & 21 & $2.70 \pm 0.69$ & $2.19 \pm 0.66$ & $82.24 \pm 12.50$ & $2.60 \pm 1.34$ & $5.47 \pm 1.11$ \\
\hline $21-30$ & 24 & $3.41 \pm 0.95$ & $2.72 \pm 0.73$ & $81.59 \pm 11.53$ & $3.49 \pm 1.99$ & $6.49 \pm 2.11$ \\
\hline $31-40$ & 9 & $2.74 \pm 0.82$ & $1.89 \pm 0.56$ & $68.79 \pm 9.56$ & $1.45 \pm 0.52$ & $4.12 \pm 1.82$ \\
\hline $41-50$ & 3 & $2.67 \pm 0.70$ & $2.09 \pm 0.46$ & $79.79 \pm 0.46$ & $2.50 \pm 1.10$ & $5.25 \pm 1.19$ \\
\hline$>50$ & 4 & $2.20 \pm 1.17$ & $1.66 \pm 0.76$ & $79.30 \pm 15.34$ & $1.41 \pm 0.38$ & $4.01 \pm 3.39$ \\
\hline Total & 61 & $2.95 \pm 0.91$ & $2.31 \pm 0.75$ & $79.69 \pm 12.41$ & $2.64 \pm 1.68$ & $5.57 \pm 2.25$ \\
\hline
\end{tabular}

The mean values \pm S.D. of FVC, $\mathrm{FEV}_{1}, \mathrm{FEV} 1 / \mathrm{FVC}, \mathrm{MMFER}$ and PEFR of all cases were $2.95 \pm 0.91 ; 2.31 \pm 0.75$; $79.69 \pm 12.41 ; 2.64 \pm 1.68$ and $5.57 \pm 2.25$ respectively.

Maximum mean values \pm S.D. of FVC, $\mathrm{FEV}_{1}$, MMFER and PEFR were observed in age group 21-30 years while maximum mean value \pm S.D. of $\mathrm{FEV}_{1} / \mathrm{FVC}$ ratio was found in $10-20$ years age group. 
Table No 4(B): Distribution of mean values \pm S.D. of pulmonary functions in total control according to different age groups

\begin{tabular}{|l|l|l|l|l|l|l|}
\hline $\begin{array}{l}\text { Age group } \\
\text { (years) }\end{array}$ & No. & FVC(lit) & FEV (lit) & $\begin{array}{l}\text { FEV } / \text { FVC } \\
(\%)\end{array}$ & $\begin{array}{l}\text { MMEFR } \\
\text { (lit/sec) }\end{array}$ & $\begin{array}{l}\text { PEFR } \\
\text { (lit/sec) }\end{array}$ \\
\hline $10-20$ & 9 & $3.64 \pm 0.87$ & $3.23 \pm 0.69$ & $86.45 \pm 2.61$ & $3.54 \pm 0.74$ & $6.96 \pm 2.04$ \\
\hline $21-30$ & 17 & $4.49 \pm 0.54$ & $3.85 \pm 0.44$ & $82.79 \pm 0.66$ & $4.17 \pm 0.42$ & $9.02 \pm 0.96$ \\
\hline $31-40$ & 7 & $3.94 \pm 0.70$ & $3.32 \pm 0.57$ & $80.71 \pm 0.62$ & $3.55 \pm 0.47$ & $8.25 \pm 1.17$ \\
\hline $41-50$ & 2 & $3.68 \pm 0.62$ & $3.08 \pm 0.41$ & $79.94 \pm 1.68$ & $3.30 \pm 0.29$ & $7.52 \pm 1.31$ \\
\hline$>50$ & 4 & $2.63 \pm 0.60$ & $2.15 \pm 0.46$ & $77.15 \pm 0.78$ & $2.28 \pm 0.20$ & $6.24 \pm 1.13$ \\
\hline Total & 39 & $3.96 \pm 0.86$ & $3.40 \pm 0.72$ & $82.54 \pm 3.08$ & $3.68 \pm 0.75$ & $8.05 \pm 1.64$ \\
\hline
\end{tabular}

The mean values \pm S.D. of FVC, FEV1, FEV1/FVC, MMEFR and PEFR were 3.96 $\pm 0.86,3.40 \pm 0.72,82.54 \pm 3.08$, $3.68 \pm 0.75$ and $8.05 \pm 1.64$ respectively.

Maximum mean values \pm SD of FVC, FEV1, MMEFR and PEFR observed in age group of 21-30 years while maximum mean value $\pm \mathrm{SD}$ of $\mathrm{FEV} 1 / \mathrm{FVC}$ ratio was found in age group 10-20 years.

Table No 5: Comparison of mean values \pm S.D. of pulmonary functions between total control and cases

\begin{tabular}{|l|l|l|l|l|l|}
\hline Subject & FVC & FEV $\mathbf{1}$ (lit) & FEV $\mathbf{1} /$ FVC(\%) & MMEFR(lit/sec) & PEFR(lit/sec) \\
\hline $\begin{array}{l}\text { Total } \\
\text { control(n=39) }\end{array}$ & $3.96 \pm 0.86$ & $3.40 \pm 0.72$ & $82.54 \pm 3.08$ & $3.68 \pm 0.75$ & $8.05 \pm 1.64$ \\
\hline $\begin{array}{l}\text { Total cases } \\
(\mathrm{n}=61)\end{array}$ & $2.95 \pm 0.91$ & $2.32 \pm 0.75$ & $79.69 \pm 12.41$ & $2.64 \pm 1.68$ & $5.57 \pm 2.25$ \\
\hline 't' value & 5.54 & 7.14 & 1.40 & 3.62 & 5.93 \\
\hline 'p' value & $<0.001$ & $<0.001$ & $\begin{array}{l}>0.05 \\
\text { N.S. }\end{array}$ & $<0.001$ & $<0.001$ \\
\hline
\end{tabular}

The mean values \pm S.D. of all spirometric parameters showed low value in cases in comparison to control. Statistically all parameters showed highly significant difference ('p' value were $<0.001$ ) except in FEV1/FVC ratio ('p' value was $>0.05$ )

Table No 6: Comparison of mean values \pm S.D. of different haematological and lung functions values between before and after treatment with diethyl carbamazine therapy

\begin{tabular}{|c|c|c|c|c|c|c|}
\hline $\begin{array}{l}\text { Treatment } \\
\text { Status }\end{array}$ & $\begin{array}{l}\text { AEC } \\
\left(/ \mathbf{m m}^{3}\right)\end{array}$ & $\begin{array}{l}\text { FVC } \\
\text { (lit) }\end{array}$ & $\begin{array}{l}\text { FEV1 } \\
\text { (lit) }\end{array}$ & $\begin{array}{l}\text { FEV } 1 / \text { FVC } \\
(\%)\end{array}$ & $\begin{array}{l}\text { MMEFR } \\
\text { (lit/sec) }\end{array}$ & $\begin{array}{l}\text { PEFR } \\
\text { (lit/sec) }\end{array}$ \\
\hline $\begin{array}{l}\text { Before } \\
\text { Treatment } \\
(n=13)\end{array}$ & $\begin{array}{l}12,154.08 \\
\pm 4,285.06\end{array}$ & $\begin{array}{l}2.81 \\
\pm 0.66\end{array}$ & $\begin{array}{l}2.30 \\
\pm 0.69\end{array}$ & $\begin{array}{l}81.01 \\
\pm 9.91\end{array}$ & $\begin{array}{l}2.23 \\
\pm 0.87\end{array}$ & $\begin{array}{l}5.13 \\
\pm 2.04\end{array}$ \\
\hline $\begin{array}{l}\text { After } \\
\text { Treatment } \\
(\mathrm{n}=13)\end{array}$ & $\begin{array}{l}690.46 \\
\pm 225.90\end{array}$ & $\begin{array}{l}2.87 \\
\pm 0.84\end{array}$ & $\begin{array}{l}2.53 \\
\pm 0.73\end{array}$ & $\begin{array}{l}81.22 \\
\pm 7.96\end{array}$ & $\begin{array}{l}2.44 \\
\pm 0.85\end{array}$ & $\begin{array}{l}5.78 \\
\pm 2.21\end{array}$ \\
\hline 't' value & 9.63 & 0.18 & 0.84 & 0.06 & 0.60 & 0.77 \\
\hline 'p'value & $<0.001$ & $\begin{array}{l}>0.10 \\
\text { N.S. }\end{array}$ & $\begin{array}{l}>0.10 \\
\text { N.S. }\end{array}$ & $\begin{array}{l}>0.10 \\
\text { N.S. }\end{array}$ & $\begin{array}{l}>0.10 \\
\text { N.S. }\end{array}$ & $\begin{array}{l}>0.10 \\
\text { N.S. }\end{array}$ \\
\hline
\end{tabular}


Research Article

Treatment was given with standard doses of diethylcarbamazine citrate $(6 \mathrm{mg} / \mathrm{kg} /$ day $)$ in three divided dosage for 21 days. After treatment, improvement was observed in all parameters of haematological and lung functions but statistically, highly significant difference (' $p$ ' $<0.001$ ) was observed in haematological parameters that is in AEC, while non significant difference (' $p$ ' $>0.10$ ) was observed in all parameters of lung functions.

Table No 7: Comparison of mean values \pm S.D. of pulmonary functions between normal healthy control and TPE cases after treatment

\begin{tabular}{|l|l|l|l|l|l|}
\hline & $\begin{array}{l}\text { FVC } \\
\text { (lit) }\end{array}$ & $\begin{array}{l}\text { FEV }_{\mathbf{1}} \\
\text { (lit) }\end{array}$ & $\begin{array}{l}\text { FEV }_{\mathbf{1}} / \text { FVC } \\
\mathbf{( \% )}\end{array}$ & $\begin{array}{l}\text { MMEFR } \\
\text { (lit/sec) }\end{array}$ & $\begin{array}{l}\text { PEFR } \\
\text { (lit/sec) }\end{array}$ \\
\hline $\begin{array}{l}\text { After treatment } \\
(\mathrm{n}=13)\end{array}$ & $2.87 \pm 0.84$ & $2.53 \pm 0.73$ & $81.22 \pm 7.96$ & $2.44 \pm 0.85$ & $5.78 \pm 2.21$ \\
\hline Control (n=39) & $3.96 \pm 0.86$ & $3.40 \pm 0.72$ & $82.54 \pm 3.08$ & $3.68 \pm 0.75$ & $8.05 \pm 1.64$ \\
\hline 't' value & 4.01 & 3.73 & 0.87 & 4.99 & 3.95 \\
\hline 'p' value & $<0.001$ & $<0.001$ & $\begin{array}{l}>0.10 \\
\text { N.S. }\end{array}$ & $<0.001$ & $<0.001$ \\
\hline
\end{tabular}

Statistically, on comparison between after treatment and control showed highly significant difference in all parameters ('p' value $<0.001$ ), except in $\mathrm{FEV}_{1} / \mathrm{FVC}$ ratio ('p'>0.10).

After the treatment, the mean values \pm S.D. of all parameters in cases showed improvement but the values were still below the control value.

\section{Discussion}

The present study was undertaken to assess the pulmonary functions in cases of tropical pulmonary eosinophilia .Pulmonary function test were carried out in 100 subjects; 61 were cases and 39 were controls. In the present study, out of 61 cases of TPE, 49(80.3\%) were males and $12(19.7 \%)$ were females. The male to female ratio was approximately $4: 1$. Almost similar male preponderance was reported by Kamat et al [20]; Udwadia [2]; Vijayan et al [17]; Rom et al [21] and Sandhu et al [22].

In the present study, the mean age $\pm \mathrm{SD}$ of cases was $27.44 \pm 11.72$ (ranged from 14 to 62 years). $74 \%$ of total cases were below 30 years, with only four $(6.5 \%)$ cases were above 48 years of age. The mean age \pm SD of male and female cases were $25.92 \pm 9.96$ and $35.20 \pm 16.85$ years respectively. The finding of the present study showed correlation with studies done by Vijayan et al that studied 50 cases of tropical pulmonary eosinophilia with mean age \pm SD of $24.1 \pm 7.5$ years (ages ranged from 12 to 48 years)[17]. Rom et al studied 23 cases of tropical pulmonary eosinophilia. The mean age of their cases was $26 \pm 2$ years [21]. Vijayan et al studied 50 cases of tropical pulmonary eosinophilia, with ages ranging from 14 to 48 years, with $84 \%$ of their cases were below 30 years of age[12].

In the present study commonest symptom found was cough in $100 \%$ cases (dry, $47.5 \%$ and productive,
$52.5 \%)$ followed by breathlessness $(93.4 \%)$, wheezing (45.9\%),chest pain(50.8\%).The frequency of symptoms found in present study showed correlation with frequency of previous study done by Udwadia found cough in $90 \%$ of cases followed by breathlessness in $70 \%$, fever $35 \%$, wheezing (28\%), chest pain(10\%)[2]. Rom et al found both cough and dyspnoea in $100 \%$ cases, followed by nocturnal wheezing (70\%) and chest pain (39\%) [21]. Vijayan et al also described symptoms on presentation were cough in $100 \%$ cases followed by dyspnoea (94\%), wheezing(54\%), chest pain (34\%) and fever (16\%)[12].

In the present study, the mean $\mathrm{AEC} \pm \mathrm{SD}$ of total cases were $9,829.64 \pm 12,690.18 / \mathrm{mm}^{3}$ (ranged from 2,550 to 26,488). $36 \cdot 1 \%$ of these cases had AEC level above $10,000 / \mathrm{mm}^{3}$, which shows similarities with studies done by Vijayan et al that found the mean $\mathrm{AEC} \pm \mathrm{SD}$ was 9.18 $\pm 0.66 \times 10^{9} / \mathrm{L}$ (ranged from 3.1 to $23.5 \times 10^{9} / \mathrm{L}$ ). $90 \%$ of their cases had AEC level more than $5.0 \times 10^{9} / \mathrm{L}[12]$. Sharma et al found that the mean AEC \pm SD was $14,880 \pm 18,710 / \mathrm{mm}^{3}$ (ranged from 8,142 to 21,618 )[23] Sandhu et al found that the mean \pm SD was $9,401 \pm 8,556 / \mathrm{mm}^{3}$ (ranged from 2,500 to 30,750 )[22] .

In this study the mean values $\pm \mathrm{SD}$ of FVC; $\mathrm{FEV}_{1}$; MMEFR and PEFR of cases were significantly lower than that of controls. The findings of present study showed correlation with various studies. Panda et al found that the mean values $\pm \mathrm{SD}$ of $\mathrm{VC} ; \mathrm{FEV}_{1}$ and 
Research Article

maximal expiratory flow rate (MMEFR) were significantly reduced in cases as compared to control (' $p$ ' $<0.01)$.[24]. Singh et al found that the mean values \pm SD of $\mathrm{VC} ; \mathrm{FEV}_{1} ; \mathrm{FEV}_{1} / \mathrm{FVC}$ ratio; PEFR and MMEFR were significantly lower in the diseased group in comparison to control.[25]. Sharma et al found mild reduction in FVC, PEFR and MMEFR in cases [23].

In the present study, after treatment, improvement was observed in all parameters of haematological and lung functions but statistically, highly significant difference ('p' $<0.001)$ was observed in all haematological parameters, while no significant difference (' $p$ ' $>0.10$ ) was observed in all parameters of lung functions. The mean values $\pm \mathrm{SD}$ of $\mathrm{AEC}$ was fell significantly from $12,154.08 \pm 4,285.06 / \mathrm{mm}^{3}$ to $690.46 \pm$ $225.90 / \mathrm{mm}^{3}$. Statistically on comparison between after treatment and control showed highly significant difference in all lung functions parameters ('p'<0.001), except in $\mathrm{FEV}_{1} / \mathrm{FVC}$ ratio ('p'>0.10).

These findings are comparable with various studies done previously by kamat et al observed significant improvement for $\mathrm{FEV}_{1}$ and PEFR after therapy with diethylcarbamazine, but for FVC the increase was not significant [26]. Panda et al observed significant increase in the $\mathrm{VC}, \mathrm{FEV}_{1}$, and MMEFR after treatment with diethylcarbamazine [24]. Pinkston et al observed peripheral blood eosinophilia fell significantly after therapy from $8.7 \pm 1.2 \times 10^{3} / \mu 1$ to $2.2 \pm 0.5 / \mu 1$ ('p'< $0.05)$.pulmonary function tests demonstrate decreased $\mathrm{VC}$ and $\mathrm{FEV}_{1 .}$ [27].Singh et al observed after treatment diethylcarbamazine, significant improvement ( $p$ ' $<0.05)$ for $\mathrm{FEV}_{1}$ in patients having duration of symptoms for less then 3 months; other parameters however, did not show a significant improvement. Highly significant improvement ('p'<0.01) was found in fell in absolute eosinophil counts [25]. Rom et al observed after therapy with diethylcarbamazine, $\mathrm{FEV}_{1}$ although improved but found lower than normal group [21]. Vijayan et al observed after therapy with diethylcarbamazine, peripheral eosinophil count fell from $3.1 \pm 23.5 \times 10^{9} / \mathrm{L}$ to $2.82 \pm 0.36 \times 10^{9} / \mathrm{L}\left({ }^{\prime} \mathrm{p} '<0.001\right)[12]$.

Patients of tropical pulmonary eosinophilia cases showed significant improvement clinically, haematologically and spirometrically after treatment with standard dose of diethylcarbamazine for three weeks but some lung function abnormality persisted even after therapy.

\section{Conclusion}

On comparison between after treatment and control, significant improvement was observed in lung functions but the values were still below the control values. Patients of tropical pulmonary eosinophilia cases showed significant improvement clinically, hematologically and spirometrically after treatment with standard dose of diethyl carbamazine for three weeks but some lung function abnormality persisted even after therapy.

\section{Funding: Nil}

\section{Conflict of interest: Nil}

\section{Permission from IRB: Yes}

\section{References}

1.Vijayan VK. Immunopathogenesis and treatment of eosinophilic lung diseases in the tropics. In: Sharma OP (Ed). Tropical Lung Diseases (Lung Biology in Health and Disease). New York: Marcel Dekker Inc., 2006;211:195-239.

2. Udwadia FE. Tropical eosinophilia. In: Herzog H (Ed). Pulmonary Eosinophilia; Progress in Respiration Research. Basel; S Karger; 1975. pp. 35-155.

3. Otteses EA, Nutman TB. Tropical pulmonary eosinophilia. Ann Rev Med. 1992;43:417-24.

4. Vijayan VK. Tropical pulmonary eosinophilia. Curr Opin Pulm Med. 2007;13:428-33.

5. Stuiver PC, Wismans PJ, Schornagel R. Tropical eosinophilia is an important disease in the Netherlands. Ned Tijdschr Geneeskd. 1991;135:283-6.

6.Neva FA, Ottesen EA. Tropical (filarial) eosinophilia. N Engl J Med 1978; 289 : 1129-31.

7.Ottesen EA. Immunological aspects of lymphatic filariasis and onhocerciasis. Trans R Soc Trop Med Hyg 1984; 73 (Suppl): 9-18.

8. Viswanathan R, Prasad M, Prasad S, Saran R, Sinha TR, Sinha SP. Morbidity survey of jail population. Part I: Incidence of certain chronic respiratory diseases with special reference to pulmonary eosinophilosis. Indian $J$ Chest Dis 1965; 7 : 142-5.

9. Ong RK, Doyle RL. Tropical pulmonary eosinophilia. 16. Chest 1998; $113: 1673-9$.

10. Hayashi K, Horiba M, Shindou J, Sumida T, Takekoshi A. Tropical eosinophilia in a man from Sri Lanka. Nihon Kyobu. Shikkan Gakkai Zasshi. 1996;34:1411-5. 
11. Jiva TM, Israel RH, Poe RH. Tropical pulmonary eosinophiliamasquerading as acute bronchial asthma. Respiration. 1996;63:55-8.

12.Vijayan VK, Kuppurao KV, Sankaran K, Venkatesan P, Prabhakar R. Tropical eosinophilia: clinical and physiological response to diethylcarbamazine. Respir Med 1991; $85: 17-20$.

13. Udwadia FE. Tropical eosinophilia - a correlation of clinical, histopathologic and lung function studies. Dis Chest 1967; 52 : 531-8.

14. Kuppurao KV, Vijayan VK, Venkatesan P, Sankaran $\mathrm{K}$. Effect of treatment on maximal expiratory flow rates in tropical eosinophilia. Ceylon Med J 1993; 38 : 78-80.

15. Vijayan VK, Kuppurao KV, Venkatesan P, Sankaran K, Prabhakar R. Pulmonary membrane diffusing capacity and capillary blood volume in tropical eosinophilia. Chest 1990; 97 : 1386-9.

16. Danaraj TJ. The treatment of eosinophilic lung (Tropical eosinophilia) with diethylcarbamazine. Quart J Med. 1958;27: 243-63.

17. Vijayan VK, Kuppurao KV, Sankaran K, Venkatesan P, Prabhakar R. Diffusing capacity in acute untreated tropical eosinophilia. Indian J Chest Dis Allied Sci. 1988;30:71-77.

18. Vijayan VK, Kuppurao KV, Sankaran K, Venkatesan P, Prabhakar R. Pulmonary membrane diffusing capacity and capillary blood volume in tropical eosinophilia. Chest. 1990;97:1386-9.

19. Kuppurao KV, Vijayan VK, Venkatesan P, Sankaran K. Effect of treatment on maximal expiratory flow rates in tropical eosinophilia. Ceylon Med J. 1993;38:78-80.

20. Kamat SR, Pimparkar BD, Store SD, Warrier NVU, Fakey 61. YC. Study of clinical radiological and pulmonary function patterns of response to treatment in pulmonary eosinophilia. Indian J Chest Dis 1970; 12 : 91-100.

21. Rom WN, Vijayan VK, Cornelius MJ, Kumaraswami V, Prabhakar R, Ottesen EA, et al. Persistent lower respiratory tract inflammation associated with interstitial lung disease in patients with tropical pulmonary eosinophilia following conventional treatment with diethylcarbamazine. Am Rev Respir Dis. 1990;142:1088-92.

22.Sandhu M, Mukhopadhyay S, Sharma SK. Tropical pulmonary eosinophilia: a comparative evaluation of plain chest radiography and computed tomography. Australas Radiol. 1996;40: 32-37.

23. Sharma SK, Pande JN, Khilnani GC, Verma K, Khanna M. Immunologic \& pulmonary function abnormalities in tropical pulmonary eosinophilia. Indian J Med Res 1995; 101 : 98-102.

24. Panda A. et al. Pulmonary function in Tropical Eosinophilia before and after treatment with diethylcarbamazine. J.A.M.A. 1985;83:11:376-8.

25.Singh R.P. et al.Ventilatory functions in Tropical Pulmonary Eosinophilia. J.A.P.I. 1989;37:12775-7.

26. Kamat SR, Warrier NVU, Store SD, Karandikar KN, D'Sa 65. E, Hoskote VR. Clinical studies in pulmonary eosinophila. I - Comparative study of response to diethylcarbamazine and corticosteroid drugs. Indian $J$ Chest Dis 1976; $18: 221-32$.

27. Pinkston P, Vijayan VK, Nutman TB, Rom WN, O'Donnell KM, Cornelius MJ, et al. Acute tropical pulmonary eosinophilia: characterization of the lower respiratory tractinflammation and its response to therapy. J Clin Invest. 1987;80:216-25

\section{How to cite this article?}

Kumar R, Mourya S. Pulmonary function test in Tropical Pulmonary Eosinophilia. Int J Med Res Rev 2014;2(4):283- 290. doi:10.17511/ijmrr.2014.i04.03 